\title{
Phytochemical Screening and Toxicological Evaluation of Sargassum wightii Greville in Wistar Rats
}

\section{Sargassum wightii Greville'nin Fitokimyasal Taraması ve Wistar Sıçanlardaki Toksikolojik Değerlendirmesi}

\author{
(D) Sathiya RAMU*, (D) Anita MURALI, (D) Anbu JAYARAMAN \\ M. S. Ramaiah University of Applied Sciences, Faculty of Pharmacy, Department of Pharmacology, Bangalore, Karnataka, India
}

\begin{abstract}
Objectives: The present study was conducted to identify the phytoconstituents present in different extracts of Sargassum wightii and to assess the toxicity of its ethanol extract.

Materials and Methods: Successive solvent extraction and total ethanol extraction of S. wightii were performed and preliminary phytochemical screening was carried out. The acute toxicity of ethanol extract of S. wightii (ESW) was studied. The subchronic toxicity of ESW was tested with doses of 100,200 , and $400 \mathrm{mg} / \mathrm{kg}$. The animals were observed for changes in body weight and food and water intake. At the end of the study, the relative weights of vital organs were noted, followed by histopathological examinations. Various hematological and biochemical estimations were also carried out.

Results: Phytochemical screening of S. wightii revealed the presence of alkaloids, carbohydrates, glycosides, phenolic compounds, and tannins. ESW did not induce any mortality or pre-terminal death in the acute toxicity study. There were no significant differences in body weight, relative weight of vital organs (except the brain), or food or water intake compared to the control group. The histopathological examination showed normal architecture, suggesting absence of pathological lesions. Hematological and biochemical parameters were also comparable to those of the control group except for reductions in glucose and cholesterol levels, which are postulated to be beneficial.

Conclusion: The presence of various phytoconstituents in S. wightii is evidence that it could be a potential source for treating different ailments. No significant toxic effects were observed after treatment with ESW. Thus, it is proposed to be safe and can be recommended for long-term treatment. Key words: Sargassum wightii, phytochemical screening, acute toxicity, subchronic toxicity
\end{abstract}

öz

Amaç: Bu çalıșma, Sargassum wightii'nin farklı ekstrelerinde bulunan fitokimyasalları tanımlamak ve etanol ekstresinin toksisitesini değerlendirmek için yapılmıştır.

Gereç ve Yöntemler: S. wightii'den total etanol ekstraksiyonu ve ardışık çözücü ekstraksiyonu yapılarak ekstreler üzerinde ön fitokimyasal tarama yapılmıştır. S. wightii'nin etanol ekstresinin (ESW) akut toksisitesi araștırılmıștır. ESW'nin subkronik toksisitesi, 100,200 ve 400 mg/kg'lik dozlarla test edilmiştir. Hayvanlar, vücut ağırlığındaki ve yiyecek ve su alımındaki değişiklikler için gözlenmiştir. Çalışmanın sonunda, hayati organların relatif ağırlıkları, ardından histopatolojik incelemeler yapılmıştır. Çeșitli hematolojik ve biyokimyasal değerlendirmeler de yapılmıştır.

Bulgular: S. wightii'nin fitokimyasal taraması, alkaloitler, karbonhidratlar, glikozitler, fenolik bileşikler ve tanenlerin varlığını ortaya koymuştur. ESW, akut toksisite çalışmasında mortalite veya terminal öncesi ölüme neden olmamıştır. Hayvanlar, vücut ağırlığındaki ve yem ve su tüketimindeki değişiklikler yönünden gözlenmiștir. Çalıșmanın sonunda, hayati organların (beyin hariç) relatif ağırlıkları, yem ve su tüketiminde kontrol grubuna kıyasla anlamlı farklılıklar bulunamamıștır. Histopatolojik incelemede patolojik lezyonların olmadığını gösteren normal bir yapı izlenmiştir. Hematolojik ve biyokimyasal parametreler, yararlı olduğu düșünülen glukoz ve kolesterol seviyelerinde azalma haricinde, kontrol grubu ile de karşılaștırılabilir düzeyde bulunmuştur.

Sonuç: S. wightii' de çeşitli fitokimyasalların varlığı, farklı hastalıkların tedavisi için potansiyel bir kaynak olabileceğinin kanıtıdır. ESW ile tedaviden sonra önemli bir toksik etki gözlenmemiştir. Bu nedenle, güvenli olduğu ve uzun süreli tedavide kullanılabilirliği önerilmiştir.

Anahtar kelimeler: Sargassum wightii, fitokimyasal tarama, akut toksisite, subkronik toksiste

*Correspondence: E-mail: sathya.pharma@gmail.com, Phone: +9035919823 ORCID: orcid.org/0000-0003-3474-7033

Received: 01.06.2018, Accepted: 31.08 .2018

๑Turk J Pharm Sci, Published by Galenos Publishing House. 


\section{INTRODUCTION}

Sargassum is a significant genus of brown marine algae belonging to the family Sargassaceae. The well-known bioactive compounds of Sargassum include meroterpenoids, phlorotannins, fucoidans, sterols, and glycolipids. It is reported to possess antioxidant, hypolipidemic, hypoglycemic, neuroprotective, antimicrobial, anticancer, anti-inflammatory, anticoagulant, antimelanogenic, and hepatoprotective activities. $^{1-9}$

Sargassum wightii Greville (S. wightii) is an abundant marine brown alga commonly found on the shorelines of India. It is dark brown, $21-40 \mathrm{~cm}$ in height, richly branched, and the midrib is spherical to ellipsoidal and 5-8 $\mathrm{mm}$ long and 2-4 mm wide. ${ }^{10}$ It is a macroscopic, multicellular, photosynthetic, nonvascular, pelagic marine species rich in sulfated polysaccharides that manifest potent free radical scavenging and antioxidant effects and hypolipidemic and anti-inflammatory effects. ${ }^{11-13}$ Fucoidan is one of the well-known components of S. wightii with diverse biological activities including anti-inflammatory, anticancer, antimicrobial, and $\alpha$-D-glucosidase inhibitory activity. ${ }^{14}$ The present study was designed to screen the phytoconstituents present in different extracts of S. wightii and to assess the toxicity of total ethanol extract of S. wightii. Ethanol extract was chosen for the toxicity study as it is known to possess various potent bioactive phytoconstituents compared to other solvent extracts and also because of interest in further pharmacological studies with ethanol extract of S. wightii.

\section{MATERIALS AND METHODS}

\section{Study material}

Fresh seaweed of S. wightii was collected from coastal regions of Rameshwaram, Tamil Nadu, India, during October 2015. It was authenticated by Dr. Yoganarasimhan, a taxonomist, and a voucher specimen (\#52) was prepared as per the guidelines and deposited at the Herbarium of the Faculty of Pharmacy, M. S. Ramaiah University of Applied Sciences, Bangalore, for future reference.

During collection, the seaweed was washed thoroughly with sea water to get rid of any superfluous matter such as sand particles, salt, epiphytes, or any other foreign materials. Later, the seaweed was thoroughly washed with running tap water and then distilled water. It was shade dried at room temperature, powdered, and then packed in airtight containers. The study material was stored in a refrigerator for further study. Macroscopic analysis including the size, shape, color, base, and margin of S. wightii was carried out. ${ }^{4}$

\section{Extraction}

\section{Successive solvent extraction}

Successive solvent extraction of S. wightii was carried out using a Soxhlet apparatus. The solvent order was according to their polarity such as petroleum ether, toluene, chloroform, 95\% ethanol, and cold maceration. The extract with each solvent was filtered and dried to concentrate. The color and consistency of the extracts were noted and the percentage yield was calculated.

\section{Total alcohol extraction}

The coarsely powdered plant material was defatted using petroleum ether $\left(60-80^{\circ} \mathrm{C}\right)$ and extracted using $95 \% \mathrm{v} / \mathrm{v}$ ethanol in a Soxhlet apparatus. The extract was filtered and evaporated and accurate weight of the extract was recorded. The color and consistency of the extracts were noted and percentage yield was calculated.

\section{Phytochemical screening}

Preliminary phytochemical screening was carried out for the extracts obtained from successive solvent extraction and total alcohol extraction according to standard procedures. ${ }^{15}$

\section{Toxicity studies}

\section{Experimental animals}

All the animals used for this study were obtained from the Animal House Facility, Faculty of Pharmacy, M. S. Ramaiah University of Applied Sciences (Registration number: 220/ PO/ReBi/S/2000/CPCSEA/ 02.05.2016). Acute toxicity was carried out on three female Wistar rats. For the subchronic toxicity study, Wistar rats of either sex weighing between 195 and $235 \mathrm{~g}$ were used in the present study. They were divided into four groups, each group consisting of six animals.

The animals were housed in polypropylene cages. The temperature in the experimental animal room was maintained at $22^{\circ} \mathrm{C}\left( \pm 3^{\circ} \mathrm{C}\right)$, with relative humidity $50-60 \%$ and artificial lighting, the sequence being $12 \mathrm{~h}$ light, $12 \mathrm{~h}$ dark. Each animal in the cage was marked on the tail with methylene blue dye for appropriate identification. Food but not water was withheld overnight for the experimental animals. The experimental procedures were conducted in accordance with the guidelines provided by the Institutional Animal Ethics Committee and prior approval was obtained with the approval no. MSRFPH/PFP$59 / 2015$.

\section{Acute toxicity study}

The acute toxicity study was designed as per the OECD Guidelines $423 .^{16}$ Although S. wightii is a traditional medicine, with no reports of mortality ${ }^{17,18}$ even in large doses, a limit test was carried out. A single oral dose $(2000 \mathrm{mg} / \mathrm{kg}$ ) of ethanol extract of S. wightii (ESW) was given to three female Wistar rats.

After dosing, for the first $30 \mathrm{~min}$, the animals were monitored individually. They were given special attention for the first $4 \mathrm{~h}$ for any toxic signs. The observation was extended first to 24 $\mathrm{h}$ and then daily thereafter for a total of 14 days. The animals were observed individually for any toxic signs or pre-terminal deaths and they were recorded if they occurred. Once a week, individual body weight was monitored in all the animals to determine any drastic changes. The color and consistency of feces and changes in fur and skin, mucous membranes (nasal), and eyes of the animal were observed on a weekly basis.

Physical observations such as changes in the circulatory (heart rate), respiratory (rate), autonomic (piloerection, lacrimation, salivation, urinary incontinence, and defecation), and central nervous system (drowsiness, ptosis, gait, eye prominence, 
eyelid closure, convulsions, biting, Straub's test, motor incoordination, writhing, stereotypy, aggression, righting reflex, pinnal reflex, corneal reflex, tremors, and convulsions) were monitored and recorded if present.

\section{Subchronic toxicity}

The subchronic toxicity study was carried out as per OECD guidelines $407 . .^{19}$ The animals were divided into four groups, each group consisting of six animals. The grouping of animals was as follows:

Group I - Normal control vehicle treated 1\% sodium CMC.

Group II - Ethanol ESW 100 mg/kg (low dose).

Group III - Ethanol ESW 200 mg/kg (medium dose).

Group IV - Ethanol ESW 400 mg/kg (high dose).

Group I received 1\% sodium CMC, while groups II-IV received ESW in doses of 100,200 , and $400 \mathrm{mg} / \mathrm{kg}$ orally once daily for 28 days. The doses were selected depending on the results obtained from the acute toxicity study. Dosing time was kept constant to minimize any biological variation among animals.

At the end of the study, the animals were anesthetized and a blood sample was collected through the retro-orbital plexus into nonheparinized tubes for biochemical parameters and heparinized tubes for hematological parameters. Biochemical analysis was carried out to explore major toxic effects in tissues, specifically the liver and kidney. Biochemical investigations included sodium, potassium, ${ }^{20}$ glucose, ${ }^{21}$ total protein and albumin,, ${ }^{22-24}$ urea, ${ }^{25}$ creatinine, ${ }^{26}$ total cholesterol, ${ }^{27,28}$ alanine amino transferase (ALT), and aspartate amino transferase (AST). ${ }^{29}$ Hematological parameters such as hemoglobin content, total leucocyte count, erythrocyte count, and platelet count were estimated. ${ }^{30}$ Urine analysis was carried out during the last week of the study and included timed urine volume and $\mathrm{pH}^{31}$

All animals in the study were subjected to a complete, detailed gross necropsy. It included thorough examination of the external surface of the body, all orifices, and thoracic, cranial and abdominal cavities. The vital organs such as the liver, lungs, spleen, brain, kidneys, and heart were isolated and adherent tissue was cleared. The wet weight of organs was recorded immediately after dissection to avoid drying. Individual organs were also examined macroscopically for any gross lesions in all the animals. The following tissues were preserved in the fixation medium for histopathological examination: brain, stomach, small intestines, liver, kidneys, spleen, heart, lungs, bone, testes, ovary, and pancreas.

\section{Statistical analysis}

The data were expressed as mean \pm standard error of the mean $(n=6)$. Significant differences between groups were determined using one-way ANOVA, followed by Tukey's multiple comparison test. $P<0.05$ was considered significant.

\section{RESULTS}

The macroscopic characters of $S$. wightii leaves were as follows: 4 to $8 \mathrm{~cm}$ length, linear to oval, dark brown, with tapering base and entire margin. The color, consistency, and percentage yield of various extracts are presented in Table 1. The color of extracts varied from dark green and greenish brown to brown. Consistency was mostly semisolid except for the extract of cold maceration, which was solid. Percentage yield of extract ranged from 0.69 to 2.98 . The highest yield was from cold maceration (2.98\%) and the least was from toluene extraction $(0.69 \%)$. Phytochemical screening revealed the presence of alkaloids, phenolic compounds, carbohydrates, glycosides, and tannins.

\section{Acute toxicity study}

ESW did not induce any mortality or pre-terminal death. No changes were observed in salivation, lacrimation, perspiration, piloerection, micturition, or defecation. The animals were observed for ptosis, drowsiness, stereotypy, aggression, tremors, convulsion, Straub's test, motor in-coordination, and writhing and no abnormalities were observed in any of the treated animals. Gait, righting reflex, and corneal reflex were normal. Skin, fur, eyes, and body weight of the animals were also normal. Tremors, lethargy, diarrhea, and coma were not observed during the study.

\section{Subchronic toxicity study}

Body weight changes were documented on a weekly basis and the results are presented in Table 1 . The body weights of animals treated with 100, 200, and $400 \mathrm{mg} / \mathrm{kg}$ extract showed no significant changes and were comparable with those of the control group. The results of the subchronic toxicity study on food and water intake are presented in Tables 2 and 3 , respectively. Food as well as water intake was monitored in all the groups on a daily basis and the results are presented on a weekly basis. There were no significant changes in food or water intake between the control and extract-treated groups.

Table 1. Body weight changes in ESW-treated rats

\begin{tabular}{lllll} 
Groups & Group I (Control) $(\mathrm{g})$ & Group II $(100 \mathrm{mg} / \mathrm{kg})(\mathrm{g})$ & Group III $(200 \mathrm{mg} / \mathrm{kg})(\mathrm{g})$ & Group IV $(400 \mathrm{mg} / \mathrm{kg})(\mathrm{g})$ \\
\hline Day 0 & $199.67 \pm 17.47$ & $202.33 \pm 4.37$ & $195.33 \pm 4.80$ & $235.33 \pm 8.40$ \\
\hline Day 7 & $218.16 \pm 15.27$ & $214 \pm 4.03$ & $214 \pm 1.79$ & $238.33 \pm 9.98$ \\
\hline Day 14 & $216.33 \pm 14.61$ & $217.66 \pm 7.42$ & $210.83 \pm 5.52$ & $232.83 \pm 10.60$ \\
\hline Day 21 & $219.33 \pm 14.61$ & $218.83 \pm 6.18$ & $211.66 \pm 9.90$ & $232 \pm 13.53$ \\
\hline Day 28 & $224.66 \pm 5.65$ & $224.67 \pm 5.65$ & $215.33 \pm 16.95$ & $234.5 \pm 15.56$ \\
\hline
\end{tabular}

Values are expressed as mean \pm standard error of the mean; $(n=6)$

ESW: Extract of S. wightii 
The results of the biochemical analysis are reported in Table 4. There were no significant changes in parameters such as albumin, total protein, urea, creatinine, sodium, or potassium at the end of 28 days of treatment. AST and ALT did not show any significant difference in the extract-treated groups and were comparable with those in the control group.

There was a statistically significant decrease in blood glucose levels in the extract-treated groups. Cholesterol level was significantly reduced in the animals treated with doses of 100 and $200 \mathrm{mg} / \mathrm{kg}$ extract, whereas $400 \mathrm{mg} / \mathrm{kg}$ did not show any significant differences.

Hematological parameters were estimated at the end of 28 days and the results are presented in Table 5. There were slight variations but no significant changes in the levels of red blood cells (RBC), white blood cells (WBC), platelets, or hemoglobin in the extract-treated groups when compared to the normal group. The results of urine analysis (Table 6 ) were comparable with those of the control group.

The gross anatomy of every organ was examined macroscopically by direct observation. The macroscopic architecture of organs was normal in all the treatment groups and there were no signs of abnormalities. The organ weight of the control and extract-treated animals were noted at the end of the study (Table 7 ). There were no significant changes in the weights of vital organs including the heart, kidney, liver, spleen, and lungs, whereas there was a slight increase in the weight of the brain with the dose of $400 \mathrm{mg} / \mathrm{kg}$.

\section{Table 2. Food intake in ESW-treated rats}

\begin{tabular}{lllll} 
Groups & Group I (Control) $(\mathrm{g})$ & Group II $(100 \mathrm{mg} / \mathrm{kg})(\mathrm{g})$ & Group III $(200 \mathrm{mg} / \mathrm{kg})(\mathrm{g})$ & Group IV $(400 \mathrm{mg} / \mathrm{kg})(\mathrm{g})$ \\
\hline Week 1 & $22.68 \pm 0.64$ & $24.26 \pm 0.49$ & $23.41 \pm 0.97$ & $23.1 \pm 1.08$ \\
\hline Week 2 & $22.61 \pm 0.77$ & $23.17 \pm 0.99$ & $21.1 \pm 1.20$ & $23.17 \pm 1.20$ \\
\hline Week 3 & $21.58 \pm 1.89$ & $20 \pm 1.12$ & $19.95 \pm 1.59$ & $19.05 \pm 1.57$ \\
\hline Week 4 & $21.21 \pm 1.35$ & $20.52 \pm 0.58$ & $21.15 \pm 1.52$ & $21.84 \pm 1.14$ \\
\hline
\end{tabular}

Values are expressed as mean \pm standard error of the mean; $(n=6)$

ESW: Extract of S. wightii

Table 3. Water intake in ESW-treated rats

\begin{tabular}{lllll} 
Groups & Group I (Control) $(\mathrm{mL})$ & Group II $(100 \mathrm{mg} / \mathrm{kg})(\mathrm{mL})$ & Group III $(200 \mathrm{mg} / \mathrm{kg})(\mathrm{mL})$ & Group IV $(400 \mathrm{mg} / \mathrm{kg})(\mathrm{mL})$ \\
\hline Week 1 & $46.7 \pm 2.71$ & $49.77 \pm 1.57$ & $48.78 \pm 2.78$ & $46.32 \pm 3.28$ \\
\hline Week 2 & $50.02 \pm 2.40$ & $52.66 \pm 1.93$ & $51.21 \pm 4.2$ & $53.69 \pm 2.77$ \\
\hline Week 3 & $55.64 \pm 1.70$ & $55.84 \pm 2.31$ & $56.3 \pm 1.87$ & $54.15 \pm 1.37$ \\
\hline Week 4 & $55.69 \pm 1.73$ & $57.92 \pm 0.99$ & $58.43 \pm 2.30$ & $52.83 \pm 1.49$ \\
\hline
\end{tabular}

Values are expressed as mean \pm standard error of the mean; $(n=6)$

ESW: Extract of S. wightii

Table 4. Biochemical parameters in ESW-treated rats

\begin{tabular}{lllll} 
Groups & $\begin{array}{l}\text { Group I } \\
\text { (Control) }\end{array}$ & Group II $(100 \mathrm{mg} / \mathrm{kg})$ & $\begin{array}{l}\text { Group III } \\
(200 \mathrm{mg} / \mathrm{kg})\end{array}$ & $\begin{array}{l}\text { Group IV } \\
(400 \mathrm{mg} / \mathrm{kg})\end{array}$ \\
\hline Glucose $(\mathrm{mg} / \mathrm{dL})$ & $82.98 \pm 2.80$ & $46.17 \pm 2.56^{\mathrm{a}}$ & $47.75 \pm 1.61^{\mathrm{a}}$ & $36.49 \pm 1.74^{\mathrm{a}}$ \\
\hline Cholesterol (mg/dL) & $78 \pm 1.78$ & $51.83 \pm 1.64^{\mathrm{b}}$ & $52.5 \pm 1.92^{\mathrm{b}}$ & $61.83 \pm 7.86$ \\
\hline Albumin (g/dL) & $3.92 \pm 0.09$ & $3.68 \pm 0.13$ & $3.48 \pm 0.09$ & $3.73 \pm 0.16$ \\
\hline Total protein (g/dL) & $7.02 \pm 0.20$ & $7 \pm 0.14$ & $6.92 \pm 0.19$ & $6.45 \pm 0.29$ \\
\hline Creatinine (mg/dL) & $0.57 \pm 0.02$ & $0.55 \pm 0.03$ & $0.57 \pm 0.01$ & $0.55 \pm 0.02$ \\
\hline ALT (U/L) & $53.83 \pm 2.69$ & $57.5 \pm 2.87$ & $53.67 \pm 1.41$ & $51.5 \pm 1.48$ \\
\hline AST (U/L) & $221.5 \pm 4.15$ & $221 \pm 3.25$ & $213.33 \pm 2.81$ & $218.5 \pm 1.89$ \\
\hline Urea $(\mathrm{mg} / \mathrm{dL})$ & $30.67 \pm 1.26$ & $34.83 \pm 0.91$ & $33 \pm 1.21$ & $32.5 \pm 1.06$ \\
\hline Sodium (mEq/L) & $150.83 \pm 1.68$ & $151.17 \pm 1.78$ & $150.33 \pm 1.08$ & $150.17 \pm 1.35$ \\
\hline Potassium (mEq/L) & $4.83 \pm 0.23$ & $4.88 \pm 0.24$ & $4.80 \pm 0.24$ & $4.92 \pm 0.21$
\end{tabular}

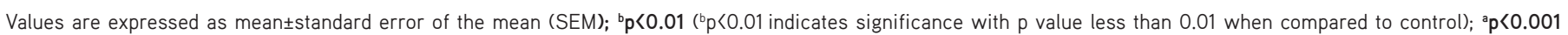
(ap<0.001 indicates high significance with $P$ value less than 0.001 when compared to control); $(n=6)$

ESW: Extract of S. wightii, ALT: Alanine amino transferase, AST: Aspartate amino transferase 
A histopathological evaluation was conducted on various organs such as the kidney, lungs, testes, ovary, bone, stomach, brain, pancreas, spleen, intestine, liver, and heart. The testes showed seminiferous tubules with normal spermatogenesis in the low dose-treated groups. An increase in spermatogenesis with normal architecture was observed in the medium and high dose-treated groups (Figure 1a-d). With low dose, the glomeruli appeared normal with mild tubular epithelial damage. Medium dose-treated animals showed mild infiltrations in the glomeruli with tubular epithelial cell damage and the damage was comparable to that in the control group
(Figure 2a-d). All the groups showed functionally efficient nerve fibers with normal astrocytes (Figure 3a-d). Normal pancreatic acini and pancreatic islet cells with intercalated and lobular ducts were observed in all the groups (Figure $4 a-d$ ). All the groups showed normal cardiac muscle bundles with myocytes and no signs of damage or changes were observed (Figure $5 a-d)$. Congestion of alveolar tissue with normal alveolus was observed with low doses, whereas mild infiltrations were observed in alveolar tissue with normal alveolar epithelium, alveolus, and air spaces in high doses (Figure 6a-d). All the treated groups showed normal spleens with lymphoid

\section{Table 5. Hematological parameters in ESW-treated rats}

\begin{tabular}{lllll} 
Groups & Group I (Control) & Group II $(100 \mathrm{mg} / \mathrm{kg})$ & Group III (200 mg/kg) & Group IV (400 mg/kg) \\
\hline RBC $\left(10^{6} / \mathrm{mm}^{3}\right)$ & $11.44 \pm 0.25$ & $12.32 \pm 0.24$ & $11.86 \pm 0.38$ & $11.06 \pm 0.19$ \\
\hline WBC $\left(10^{3} / \mathrm{mm}^{3}\right)$ & $10.13 \pm 0.34$ & $11.58 \pm 0.87$ & $12.75 \pm 1.02$ & $13.18 \pm 0.95$ \\
\hline Platelets (Lakhs/cu.mm) & $4.27 \pm 0.26$ & $4.30 \pm 0.21$ & $4.19 \pm 0.17$ & $4.50 \pm 0.12$ \\
\hline $\mathrm{Hb}(\mathrm{g} / \mathrm{dL})$ & $13.63 \pm 0.439$ & $13.83 \pm 0.45$ & $14.88 \pm 0.55$ & $14.47 \pm 0.52$ \\
\hline
\end{tabular}

Values are expressed as mean \pm standard error of the mean; $(n=6)$ RBC: Red blood cells, WBC: White blood cells, ESW: Extract of S. wightii, Hb: Hemoglobin

Table 6. Urine analysis of ESW-treated rats

\begin{tabular}{lllll} 
SI. no. & Animal groups & Urine volume & $\mathrm{pH}$ & Appearance \\
\hline $\mathbf{1}$ & Group I (control) & $1.5 \mathrm{~mL}$ & 7 & Clear, pale yellow \\
\hline $\mathbf{2}$ & Group II $(100 \mathrm{mg} / \mathrm{kg})$ & $2 \mathrm{~mL}$ & 7 & Clear, pale yellow \\
\hline 3 & Group III $(200 \mathrm{mg} / \mathrm{kg})$ & $1.5 \mathrm{~mL}$ & 7 & Clear, pale yellow \\
\hline 4 & Group IV ( $400 \mathrm{mg} / \mathrm{kg})$ & $1 \mathrm{~mL}$ & 7 & Clear, pale yellow \\
\hline
\end{tabular}

ESW: Extract of S. wightii

Table 7. Organ weights in ESW-treated rats

\begin{tabular}{lllll} 
Groups & Group I (Control) & Group II $(100 \mathrm{mg} / \mathrm{kg})$ & Group III $(200 \mathrm{mg} / \mathrm{kg})$ & Group IV (400 mg/kg) \\
\hline Heart $(\mathrm{g})$ & $0.833 \pm 0.042$ & $0.792 \pm 0.044$ & $0.733 \pm 0.038$ & $0.742 \pm 0.022$ \\
\hline Kidney $(\mathrm{g})$ & $0.71 \pm 0.029$ & $0.841 \pm 0.019$ & $0.818 \pm 0.042$ & $0.873 \pm 0.064$ \\
\hline Liver $(\mathrm{g})$ & $8.41 \pm 0.572$ & $7.40 \pm 0.425$ & $7.81 \pm 0.701$ & $8.60 \pm 0.972$ \\
\hline Spleen $(\mathrm{g})$ & $0.853 \pm 0.058$ & $0.855 \pm 0.103$ & $0.812 \pm 0.058$ & $0.795 \pm 0.064$ \\
\hline Brain $(\mathrm{g})$ & $1.65 \pm 0.047$ & $1.88 \pm 0.030$ & $1.80 \pm 0.094$ & $1.90 \pm 0.050^{c}$ \\
\hline Lungs $(\mathrm{g})$ & $1.69 \pm 0.096$ & $1.95 \pm 0.153$ & $2.16 \pm 0.305$ & $2.04 \pm 0.277$ \\
\hline
\end{tabular}

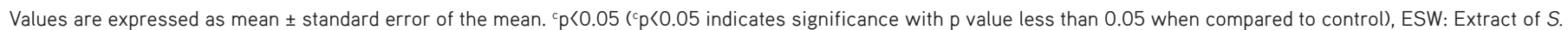
wightii

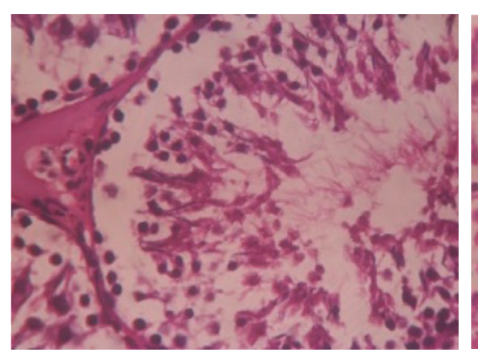

Ia) Normal control

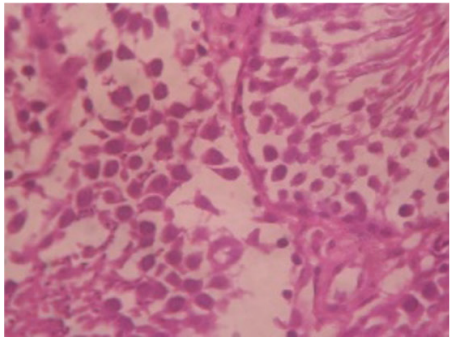

Ib) SW $100 \mathrm{mg} / \mathrm{kg}$

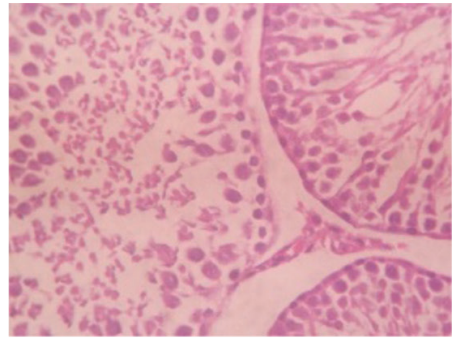

Ic) SW $200 \mathrm{mg} / \mathrm{kg}$

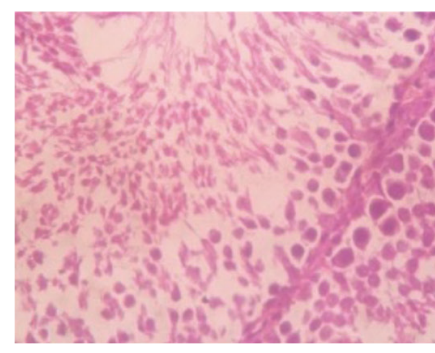

Id) SW $400 \mathrm{mg} / \mathrm{kg}$

Figure 1. Histopathology of testes 
aggregation (Figure 7a-d). Normal ovarian stroma with corpus luteum and follicles were seen in all the treatment groups (Figure 8a-d). Extract-treated groups showed gastric glands with normal parietal cells and gastric mucosa (Figure 9a-d). Normal columnar epithelial cells, intestinal villi, and goblet cells were observed in the intestine (Figure 10a-d). The bone showed normal osteoblasts with bone matrix in all the extract-treated

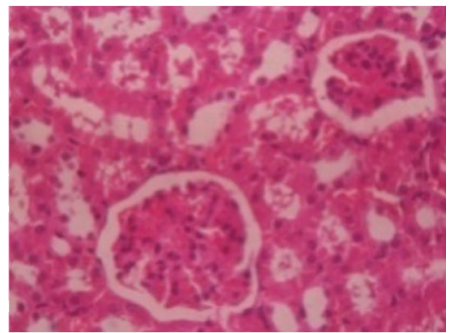

2a) Normal control

Figure 2. Histopathology of kidney

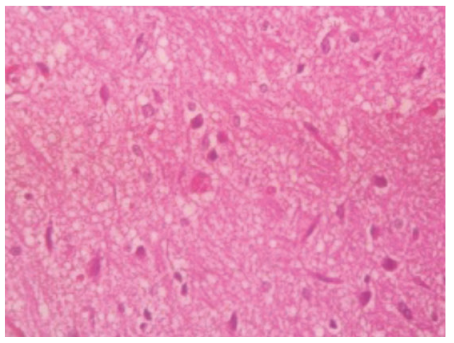

3a) Normal control

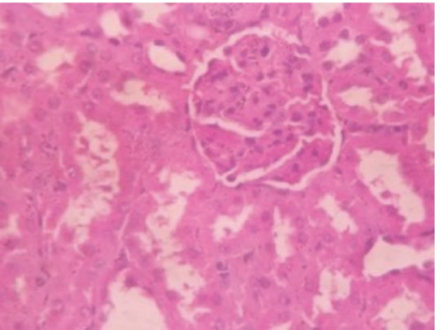

2b) SW $100 \mathrm{mg} / \mathrm{kg}$ groups (Figure 11a-d). Control group animals showed normal hepatocytes with a central vein, whereas those treated with a low dose showed normal hepatocytes with mild congestion of blood vessels and edema. Dilatation of sinusoids with normal hepatocytes was seen in the medium dose-treated animals. High dose group animals showed eosinophilic cytoplasm with mild infiltrations of mononuclear cells/heterochromatic nuclei

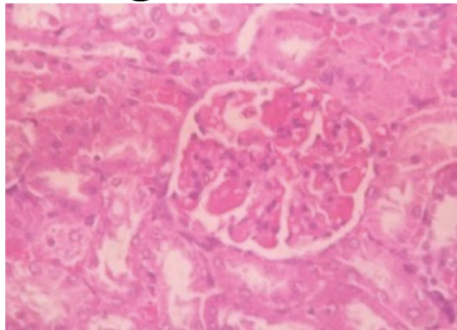

2c) SW $200 \mathrm{mg} / \mathrm{kg}$

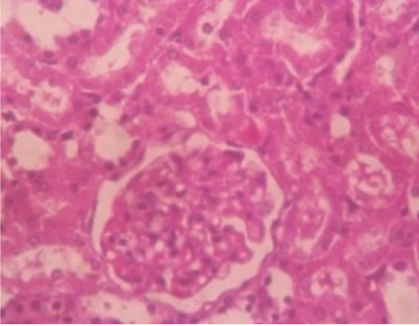

2d) SW $400 \mathrm{mg} / \mathrm{kg}$

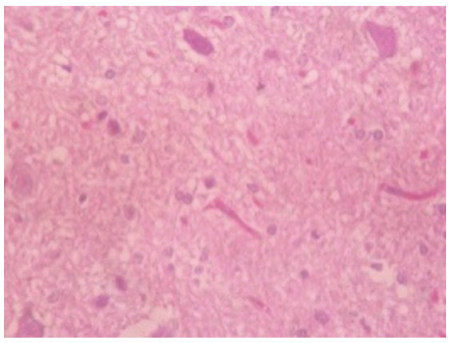

3b) SW I $00 \mathrm{mg} / \mathrm{kg}$

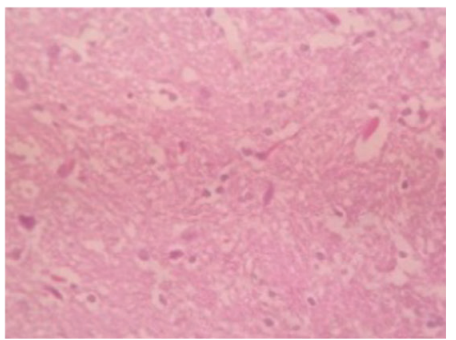

3c) SW $200 \mathrm{mg} / \mathrm{kg}$

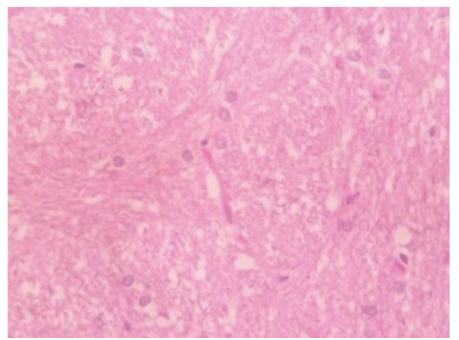

3d) SW $400 \mathrm{mg} / \mathrm{kg}$

Figure 3. Histopathology of brain

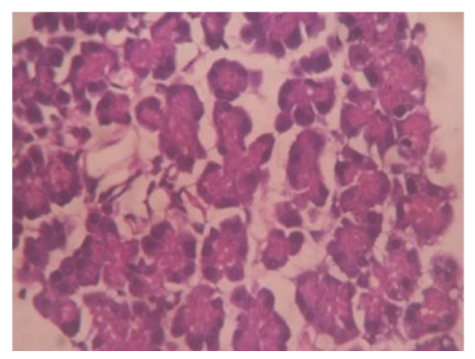

4a) Normal control

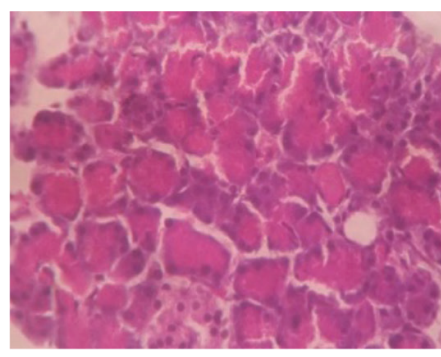

4b) SW $100 \mathrm{mg} / \mathrm{kg}$

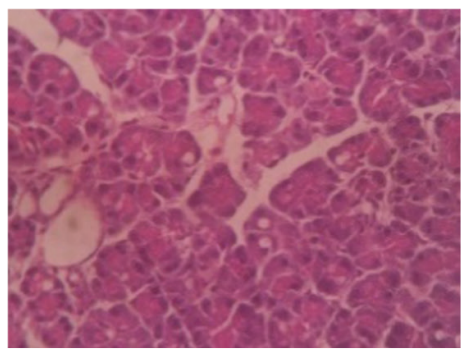

4c) SW $200 \mathrm{mg} / \mathrm{kg}$

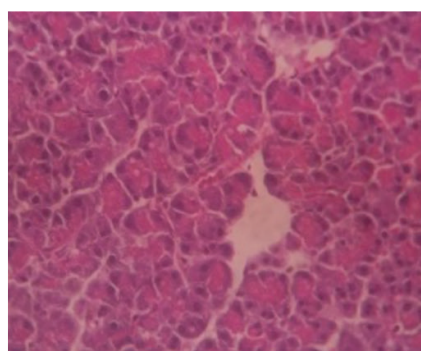

4d) SW $400 \mathrm{mg} / \mathrm{kg}$

Figure 4. Histopathology of pancreas

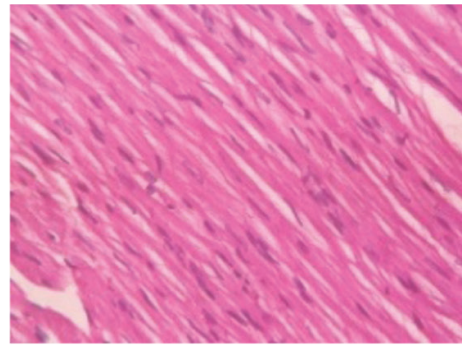

5a) Normal control

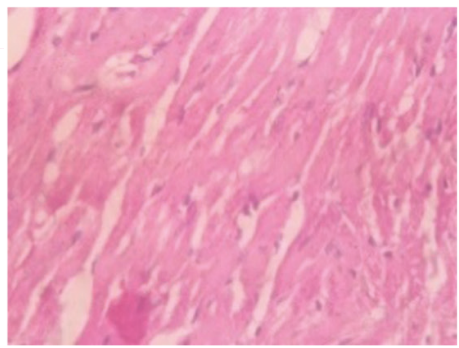

5b) SW $100 \mathrm{mg} / \mathrm{kg}$

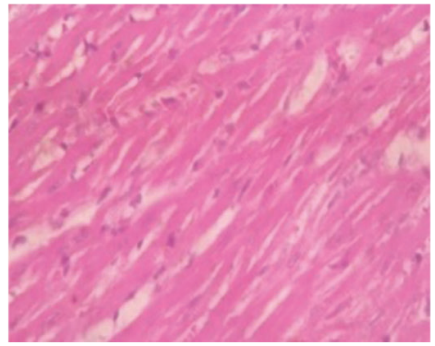

5c) SW $200 \mathrm{mg} / \mathrm{kg}$

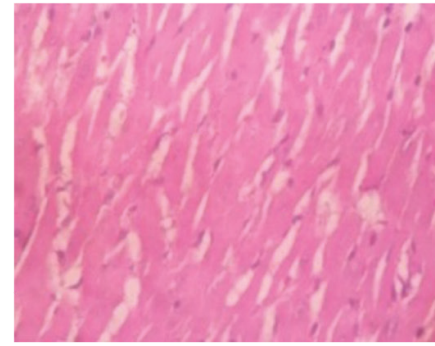

5d) SW $400 \mathrm{mg} / \mathrm{kg}$

Figure 5. Histopathology of heart 


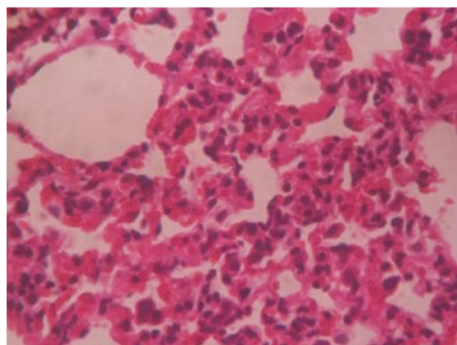

6a) Normal control

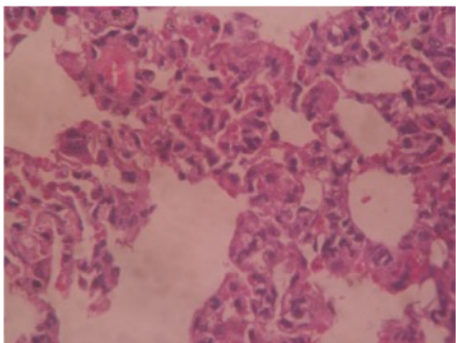

6b) SW $100 \mathrm{mg} / \mathrm{kg}$

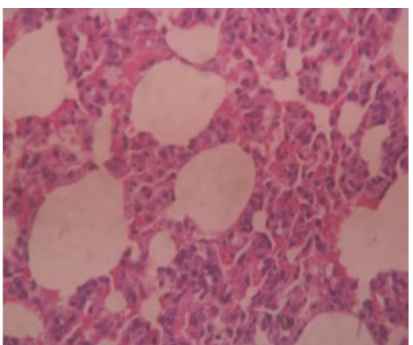

6c) SW $200 \mathrm{mg} / \mathrm{kg}$

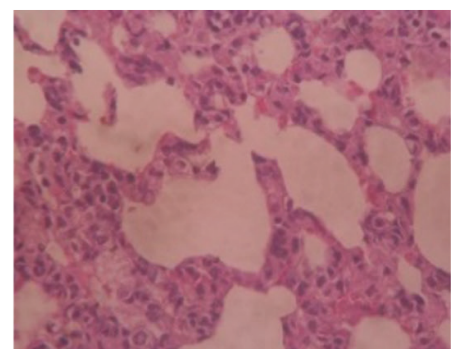

6d) SW $400 \mathrm{mg} / \mathrm{kg}$

Figure 6. Histopathology of lungs

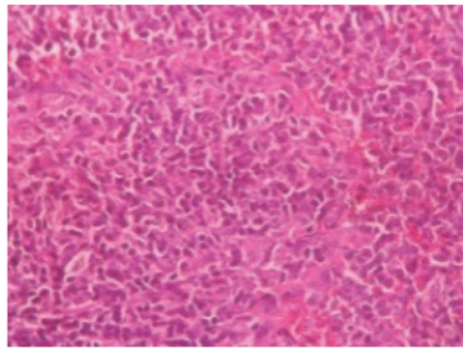

7a) Normal control

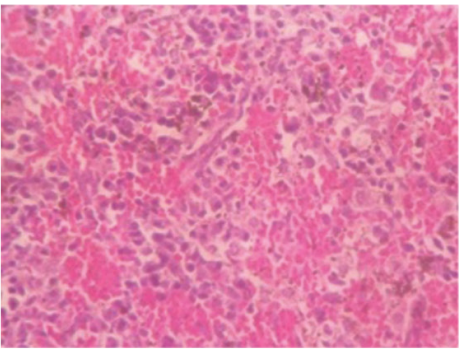

7b) SW $100 \mathrm{mg} / \mathrm{kg}$

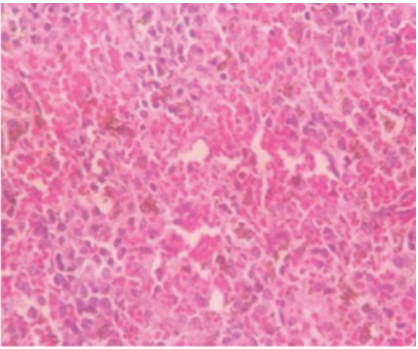

7c) SW $200 \mathrm{mg} / \mathrm{kg}$

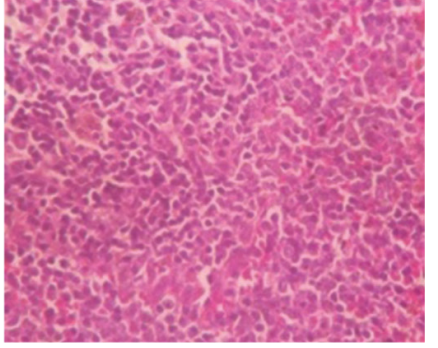

7d) SW $400 \mathrm{mg} / \mathrm{kg}$

Figure 7. Histopathology of spleen

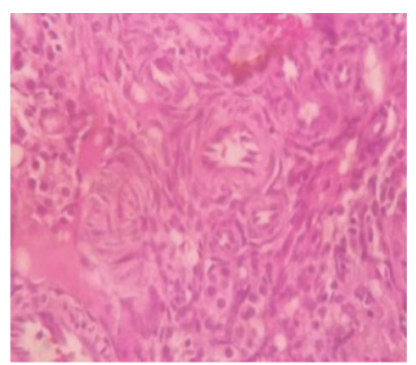

8a) Normal control

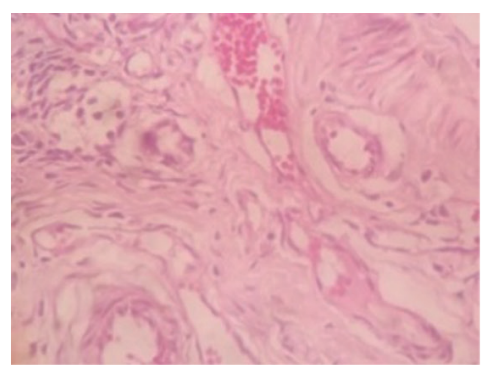

8b) SW $100 \mathrm{mg} / \mathrm{kg}$

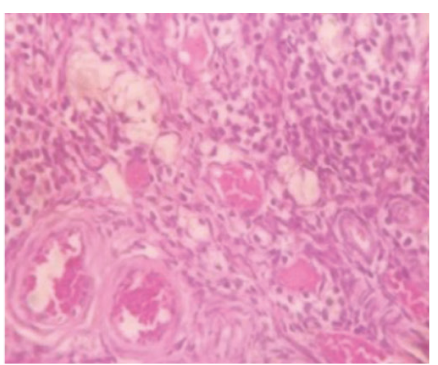

8c) SW $200 \mathrm{mg} / \mathrm{kg}$

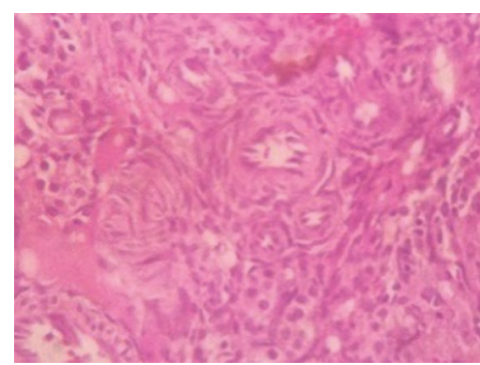

8d) SW $400 \mathrm{mg} / \mathrm{kg}$

Figure 8. Histopathology of ovary

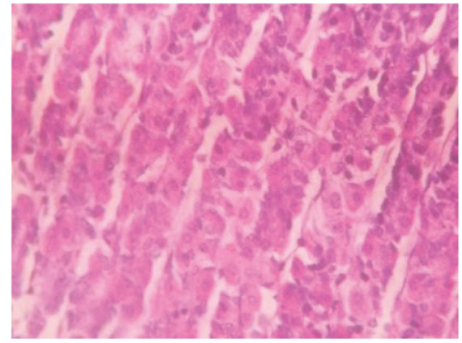

9a) Normal control

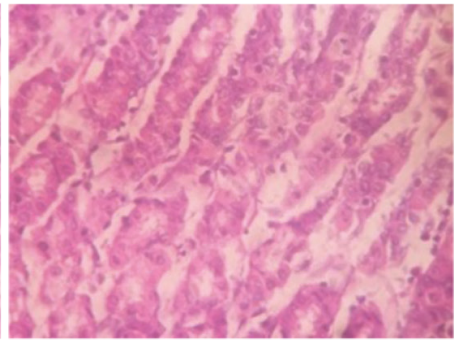

9b) SW $100 \mathrm{mg} / \mathrm{kg}$

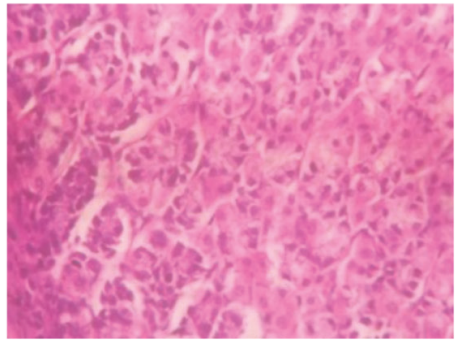

9c) SW $200 \mathrm{mg} / \mathrm{kg}$

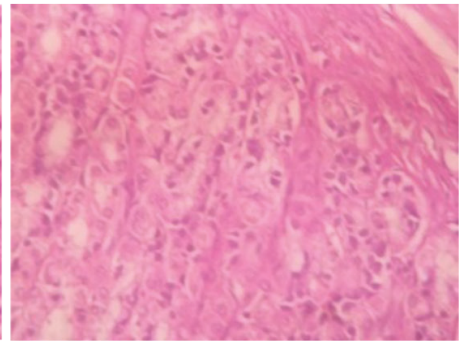

9d) SW $400 \mathrm{mg} / \mathrm{kg}$

Figure 9. Histopathology of stomach

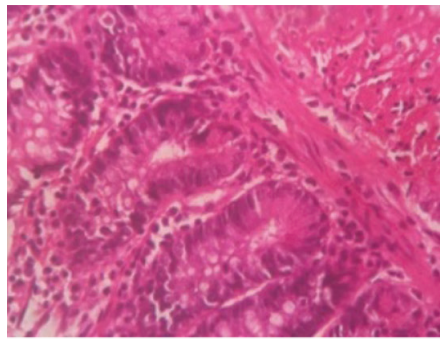

I 0a) Normal control

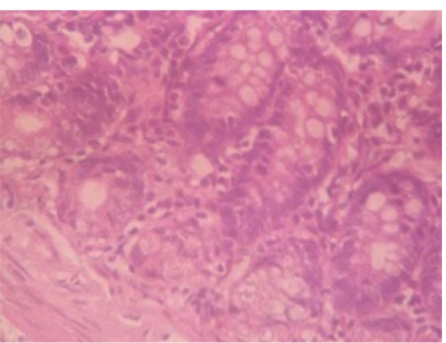

I Ob) SW $100 \mathrm{mg} / \mathrm{kg}$

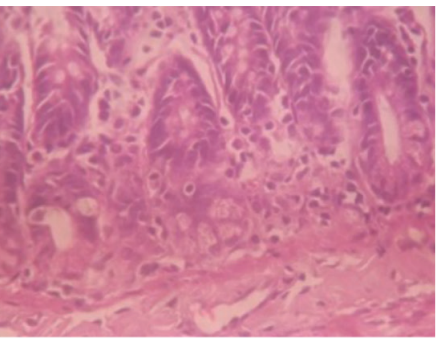

I0c) SW $200 \mathrm{mg} / \mathrm{kg}$

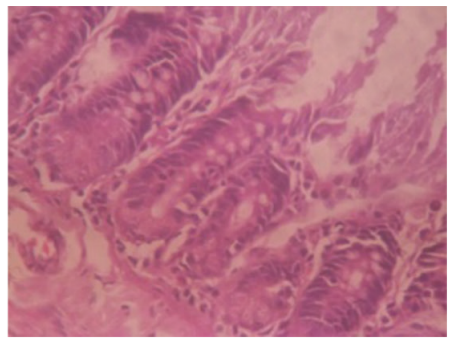

I Od) SW $400 \mathrm{mg} / \mathrm{kg}$

Figure 10. Histopathology of intestine 
(Figure 12a-d). The interpretations of all the treated groups were done in comparison with the control group.

\section{DISCUSSION}

Herbal medicines are thought to have lower risk compared to synthetic drugs, but the concept is becoming outdated since it is evident that herbal medicines also have potential risks. Various studies have reported the toxicity of herbal compounds and it becomes mandatory to rule out any such possible toxicity profile. ${ }^{32}$

The preliminary phytochemical analysis revealed the presence of many active constituents that may be pharmacologically beneficial. The animals were found to be free of any major toxic signs during as well as at the end of the acute and subchronic toxicity study. There were no abnormal signs of any motor or sensory functions.

Reduction in body weight is known to be one of the most common indices to understand the toxicity profile of drugs. ${ }^{33}$ Minor insignificant changes in body weight were observed throughout the treatment period. Any changes in food intake or water drinking pattern indicate a toxic impact on or abnormality in metabolism. ${ }^{32}$ Statistically insignificant changes in food and water intake indicate that the extract was safe for long-term administration and did not induce any alteration in the metabolic system.

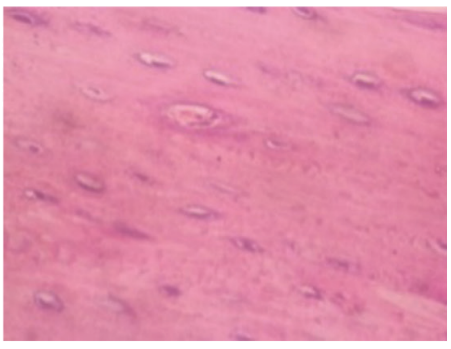

I la) Normal control

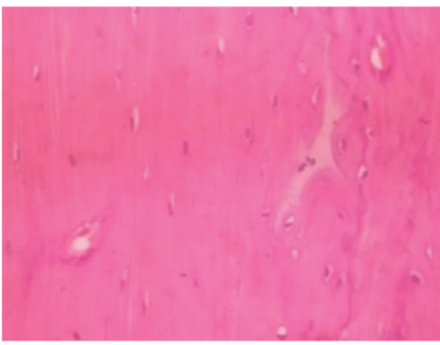

I Ib) SW $100 \mathrm{mg} / \mathrm{kg}$

Figure 11. Histopathology of bone

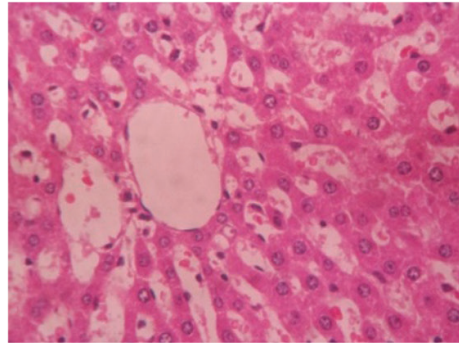

I 2a) Normal control

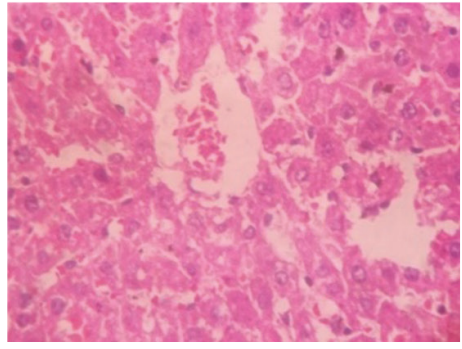

I 2b) SW $100 \mathrm{mg} / \mathrm{kg}$

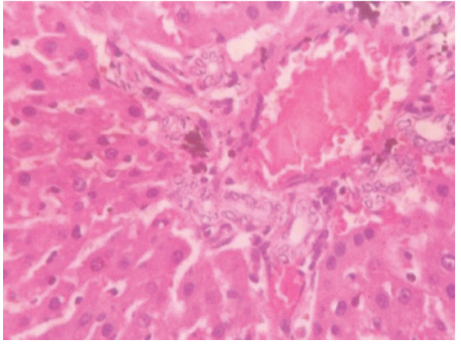

I 2c) SW $200 \mathrm{mg} / \mathrm{kg}$

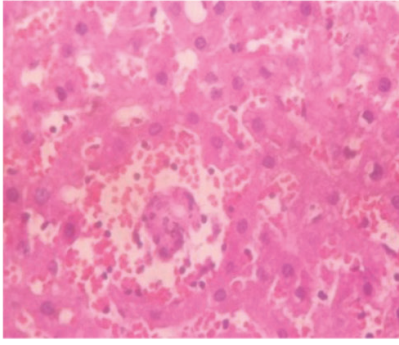

I 2d) SW $400 \mathrm{mg} / \mathrm{kg}$

Figure 12. Histopathology of liver

Groups

Group I - Normal control vehicle treated $1 \%$ sodium CMC.

Group II - Ethanol extract of S. wightii $100 \mathrm{mg} / \mathrm{kg}$ (low dose).

Group III - Ethanol extract of S. wightii $200 \mathrm{mg} / \mathrm{kg}$ (medium dose).

Group IV - Ethanol extract of S. wightii 400 mg/kg (high dose). 
The hematological system is one of the most important systems serving as an indicator of health status. It is also known to be an easy target for most toxic compounds. ${ }^{43}$ The results indicate that the ESW is nontoxic to the hematopoietic system.

Organ weight is known to be one of the main indices to derive any targeted organ toxicity. The absence of any significant differences in organ weight eliminates any such organ level toxicity. No signs of abnormality or organ level damage were observed in the macroscopic examination of gross anatomy. In the histopathological examination, all the organs showed normal architecture. Although some changes were observed, they were minimal and comparable with the observations in the control group.

Thus, the present study reveals that ESW is safe up to 2000 $\mathrm{mg} / \mathrm{kg}$ administered as a single oral dose and long-term administration of ESW does not cause toxicity to vital organs at submaximal doses, which encourages the long-term use of ESW for any further pharmacological investigations.

\section{ACKNOWLEDGEMENTS}

The authors are thankful to the Faculty of Pharmacy, M. S. Ramaiah University of Applied Sciences, for providing the required facilities and support.

Conflict of Interest: No conflict of interest was declared by the authors.

\section{REFERENCES}

1. Immanuel G, Sivagnanavelmurugan $M$, Marudhupandi $T$, Radhakrishnan S, Palavesam A. The effect of fucoidan from brown seaweed Sargassum wightii on WSSV resistance and immune activity in shrimp Penaeus monodon. Fish Shellfish Immunol. 2012;32:551-564.

2. Cho SH, Kang SE, Cho JY, Kim AR, Park SM, Hong YK, Ahn DH. The antioxidant properties of brown seaweed (Sargassum siliquastrum) extracts. J Med Food. 2007;10:479-485.

3. Kim S, Lee W, Bae G, Kim G. Anti-diabetic and hypolipidemic effects of Sargassum yezoense in $d b / d b$ mice. Biochem Biophys Res Communications. 2012;424:675-680.

4. Jin W, Zhang W, Wang J, Yao J, Xie E, Liu D, Duan D, Zhang Q. A study of neuroprotective and antioxidant activities of heteropolysaccharides from six Sargassum species. Int J Biol Macromolec. 2014;67:336-342.

5. Moubayed N, Houri H, Khulaifi M, Farraj D. Antimicrobial, antioxidant properties and chemical composition of seaweeds collected from Saudi Arabia (Red Sea and Arabian Gulf). Saudi J Biol Sci. 2017;24:162-169.

6. Zandi K, Ahmadzadeh S, Tajbakhsh S, Rastian Z, Yousefi F, Farshadpour F. Anticancer activity of Sargassum oligocystum water extract against human cancer cell lines. Eur Rev Med Pharmacol Sci. 2010;14:669-673.

7. Jeong DH, Kim KB, Kim MH, Kanq BK, Ahn DH. Anti-inflammatory activity of ethanolic extract of Sargassum micracanthum. J Microbiol Biotechnol. 2013;23:1691-1698.
8. Dore C, Alves M, Will L, Costa T, Sabry D, Rego L. A sulfated polysaccharide, fucans, isolated from brown algae Sargassum vulgare with anticoagulant, antithrombotic, antioxidant and antiinflammatory effects. Carbohydr Polym. 2013;91:467-475.

9. Hira K, Sultana V, Ara J, Haque SE, Athar M. Hepatoprotective potential of three Sargassum species from Karachi coast against carbon tetrachloride and acetaminophen intoxication. J Coast Life Med. 2016;4:10-13

10. Michael MD, Guiry GM, Algae Base. World-wide electronic publication, National University of Ireland, Galway; 2015. http:// www.algaebase.org; searched on 01 September 2015.

11. Rupérez P, Ahrazem O, Leal JA. Potential antioxidant capacity of sulfated polysaccharides from the edible marine brown seaweed Fucus vesiculosus. J Agric Food Chem. 2002;50:840-845.

12. Kolsi RBA, Salah HB, Jardak N, Chaaben R, Jribi I, Feki AE, Rebai T, Jamoussi K, Allouche N, Blecker C, Belghith H, Belghith K. Sulphated polysaccharide isolated from Sargassum vulgare: Characterization and hypolipidemic effects. Carbohydr Polym. 2017;170:148-159.

13. Coura CO, DeAraujo IW, Vanderlei ES, Rodriques JA, Quindere AL, Fontes BP, de Queiroz IN, de Menezes DB, Bezerra MM, e Silva AA, Chaves HV, Jorge RJ, Evangelista JS, Benevides NM. Antinociceptive and anti-inflammatory activities of sulphated polysaccharides from the red seaweed Gracilaria cornea. Basic Clin Pharmacol Toxicol. 2012;110:335-341.

14. Murugaiyan K, Sivakumar K. Seasonal variation in elemental composition of Stoechospermum marginatum (Ag.) Kutz and S. wightii (Greville Mscr.) J.G. Agardh in relation to chemical composition of seawater. Colloids Surf B Biointerfaces. 2008;64:140-144.

15. Devi J, Balan GS, Periyanayagam K. Pharmacognostical study and phytochemical evaluation of brown seaweed Sargassum wightii. J Coast Life Med. 2013;1:199-204.

16. OECD Guideline for Testing of Chemicals, 2001. Acute Oral Toxicity - Fixed Dose Procedure.

17. Li N, Zhang $Q$, Song J. Toxicological evaluation of fucoidan extracted from Laminaria japonica in Wistar rats. Food Chem Toxicol. 2005;43:421-426.

18. Lakshmanasenthil S, Vinothkumar T, Geetharamani D, Marudhupandi T, Suja G, Sindhu NS. Fucoidan - a novel alpha amylase inhibitor from Turbinaria ornata with relevance to NIDDM therapy. Biocatal Agric Biotechnol. 2014;3:66-70.

19. OECD Guideline for Testing of Chemicals, 2008. Repeated Dose 28Day Oral Toxicity Study in Rodents.

20. Ogbonnia SO, Nkemehule FE, Anyika EN. Evaluation of subchronic toxicity of Stachytarpheta angustifolia (Mill) Vahl (Fam. Verbanaceae) extract in animals. Afr J Biotechnol. 2009;8:1793-1799.

21. Trinder P. Determination of glucose in blood using glucose oxidase with an alternative oxygen receptor. Ann Clin Biochem. 1969;6:24-27.

22. Brobeck JR. Physiological Basis of Medical Practice (9th ed). Baltimore; Wilkins and Wilkins; 1973.

23. Doumas BT. Standards for total serum protein assays - a collaborative study. Clin Chem. 1975;1159-1166.

24. Webster BT. Estimation of protein in liquid and solid sample. Clin Chem. 1977;21:1159.

25. Chaney AL, Marbach EP. Determination of urea in liquid samples. Clin Chem. 1962;8:130 
26. Tietz NW. Fundamentals of Clinical Chemistry. Philadelphia: WB Saunders; 1976.

27. Assmann G. At what levels of total low- or high-density lipoprotein cholesterol should diet/drug therapy be initiated? European guidelines. Am J Cardiol. 1990;65:11F-15F.

28. Assmann G, Schriewer H, Schmitz G. Qualification of high density lipoprotein cholesterol by precipitation with phosphotungstic acid/ $\mathrm{Mg} / \mathrm{Cl}_{2}$. Clin Chem. 1983;29:2026-2030.

29. Bergmayer HU. Methods of Enzymatic Analysis. New York; Academic Press; 1974:1196.

30. Ghai CL. A Textbook of Practical Physiology (5th ed). New Delhi; Jaypee Brothers Medical Publishers; 2003.

31. Ghosh R, Murali, A, Sathiya R. Diuretic effects of Mitragyna parvifolia Korth. root extract and its therapeutic efficacy against experimental urolithiasis in rats. Spatula DD. 2015;5:113-121.

32. Christapher PV, Parasuraman S, Asmawi MZ, Murugaiyah V. Acute and subchronic toxicity studies of methanol extract of Polygonum minus leaves in Sprague Dawley rats. Regul Toxicol Pharmacol. 2017;86:33-41.

33. Attanayake AP, Jayatilaka K, Pathirana C, Mudduwa L. Efficacy and toxicological evaluation of Coccinia grandis (Cucurbitaceae) extract in male Wistar rats. Asian Pac J Trop Dis. 2013;3:460-466.

34. Sujith K, Darwin R, Suba V. Toxicological evaluation of ethanol extract of Anacyclus pyrethrum in albino Wistar rats. Asian Pac $J$ Trop Dis. 2012;2:437-441.

35. Senthil LS, Kumar TV, Geetharamani D, Suja G, Yesudas R, Chacko A, Fucoidan - An alpha amylase inhibitor from S. wightii with relevance to NIDDM. Int J Biol Macromol. 2015;81:644-647.
36. Kim K, Yoon K, Lee B. Fucoidan regulate blood glucose homeostasis in C57BL/KSJ $\mathrm{m}+/+\mathrm{db}$ and C57BL/KSJ db/db mice. Fitoterapia. 2012;83:1105-1109.

37. Hu S, Xia G, Wang J, Wang Y, Li Z, Xue C. Fucoidan from sea cucumber protects against high-fat high sucrose diet induced hyperglycaemia and insulin resistance in mice. J Funct Foods. 2014;10:128-138.

38. Wang D, Zhao X, Liu Y. Hypoglycemic effects of a polysaccharide from flower buds of Lonicera japonica in streptozotocin induced diabetic rats. Int J Biol Macromol. 2017;102:396-404.

39. Wang Y, Wang J, Zhao Y, Hu S, Shi D, Xue C. Fucoidan from sea cucumber Cucumaria frondosa exhibits anti-hyperglycemic effects in insulin resistant mice via activating the PI3K/PKB pathway and GLUT4. J Biosci Bioeng. 2016;121:36-42.

40. Poornima K, Krishnan R, Aswathi KV, Gopalakrishnan VK. Toxicological evaluation of ethanol extract of Tabernaemontana coronaria (L) R. Br. Asian Pac J Trop Dis. 2012;S679-S684.

41. Park J, Yeoam M, Hahm D. Fucoidan improves serum lipid levels and atherosclerosis through hepatic SREBP-2-mediated regulation. J Pharmacol Sci. 2016;131:84-92.

42. Li S, Li J, Zhi Z, Wei C, Wang W, Ding T, Ye X, Hu Y, Linhardt RJ, Chen S. Macromolecular properties and hypolipidemic effects of four sulphated polysaccharides from sea cucumbers. Carbohydr Polym. 2017;173:330-337.

43. Lynch N, Berry D. Differences in perceived risks and benefits of herbal, over-the-counter conventional, and prescribed conventional, medicines and implication of this for the safe and effective use of herbal products. Complement Ther Med. 2007;15:84-91. 